\title{
Phytochemical screening of different organic crude extracts from the stem bark of Ziziphus spina-christi (L.).
}

\author{
Essam Nabih Ads ${ }^{1,2 *}$, Saravanan Rajendrasozhan ${ }^{1}$, Syed Imran Hassan ${ }^{3}$, Sherif Mohamed Sayed \\ Sharawy $^{1,4}$, Jamal Ragheb Humaidi ${ }^{1}$ \\ ${ }^{1}$ Department of Chemistry, Faculty of Science, University of Hail, Hail, Saudi Arabia \\ ${ }^{2}$ Faculty of Science, Zagazig University, Zagazig, Egypt \\ ${ }^{3}$ Department of Chemistry, College of Science, Sultan Qaboos University, Muscat, Oman \\ ${ }^{4}$ Faculty of Science, Ain Shams University, Egypt
}

\begin{abstract}
Zizyphus spina-christi (L.) (Rhamnaceae family) is a subtropical plant known as 'Nabq' or 'Sidr' which is used for various medicinal purposes. It has used in folk medicine in pain related ailments throughout these regions. Aim of our work is to phytochemically investigate the plant's bark in our laboratory with Chromatographic approach. The crude ethanol extract of dried bark of $Z$. spina-christi (L.) was fractionated by diethyl ether, chloroform, ethyl acetate and finally with n-butanol. Finally the fractions were investigated for the chemical constituents by using gas chromatography-mass spectrometry. Thirty six compounds from the four fractions of the stem bark of $Z$. spina-christi $(L$.$) have been identified and$ recognized, especially betulin, quercetin, stigmasterol, sitosterol, ethyl oleate and phytol by means of GC-MS analyses.
\end{abstract}

Keywords: Zizyphus spina-christi (L.), Ethanol extract, Betulin, Phytol, Stigmasterol, $\alpha$-sitosterol, Quercetin. Accepted on February 17, 2018

\section{Introduction}

Ziziphus spina-christi (L.), locally known as Sidr, is a multipurpose tree species belonging to the botanical family Rhamnaceae. It is an important cultivated tree and one of the few truly native tree species of Arabia (Saudi Arabia, Jordan, and Egypt) that is still growing along with many newly introduced exotic plants [1]. It is one of the important fruit crops in the dry parts of tropical Asia and Africa. Ziziphus spina-christi (L.) fruits are highly nutritious and rich in vitamin C. Ziziphus (Rhamnaceae) species are used in folk medicine to treat blisters, bruises, chest pains, dandruff, fractures, headache, and mouth problems [2]. Ziziphus spina-christi (L.) leaves are traditionally used to treat ulcers, wounds, eye diseases, bronchitis, and skin diseases as an anti-inflammatory agent. The seeds are sedative and are used to halt nausea, vomiting and abdominal pain associated with pregnancy [3]. The fresh leaves are applied on swollen eye at night [4]. The roots are used to cure and prevent skin diseases [5]. Fruits are used to promote the healing of fresh wounds, and treat dysentery, bronchitis, coughs and tuberculosis [6]. It is also used to relief digestive disorders, obesity, urinary troubles and microbial infections $[7,8]$. Some pharmacological screening studies indicated that the aqueous extract of Ziziphus spinachristi (L.) root bark has an antinociceptive activity in mice and rats [9] and a central depressant effect in mice [10]. The methanol extract of Ziziphus spina-christi (L.) stem bark has antidiarrheal effects in rats [11].

Previous phytochemical studies on the different species of the genus Ziziphus led to the isolation and characterization of peptide, cyclopeptide alkaloids, flavonoids, sterols, tannins, betulinic acid and triterpenoidal saponin glycosides [7,12-15]. Ziziphus spina-christi (L.) extracts were evaluated for their phytochemical content in the stem bark as well as the antimicrobial and cytotoxic activities. The phytochemical analysis indicates the presence of tannins, flavonoids, terpernoids, saponin glycosides and alkaloids in Ziziphus spina-christi (L.) [16]. From the butanol extract of the leaves of Ziziphus spina-christi (L.) growing in Egypt, four triterpenoidal saponin glycosides were isolated and named christinin-A-D, respectively. Christinin-A was the major saponin [17].

Medicinal plants were investigated for phytochemical contents by GC-MS and HPLC with ethanol and hexane extracts and their toxicity by MTT and comet assay on human Peripheral Blood Mononuclear Cells (PBMCs) [18]. Phytochemical investigations on Ziziphus spina-christi (L.) have shown that this plant contains many biologically important phytochemicals. From the different species of the genus Ziziphus, peptide and cyclopeptide alkaloids, flavonoids, 
sterols, tannins, betulinic acid and triterpenoidal saponin glycosides have been isolated and chemically identified [19-21]. Betulic and ceanothic acid, three cyclopeptide alkaloids as well as four saponin glycosides [22] and several flavonoids have been isolated from the leaves of Ziziphus spina-christi (L.) [23]. This study deals with the investigation and identification of the chemical constituents by using Gas Chromatography-Mass Spectrometry (GC-MS) in the bark of Ziziphus spina-christi (L.) extracted by different organic solvents depending on polarity.

\section{Materials and Methods}

\section{Plant material}

Fresh bark of the Ziziphus spina-christi (L.) were collected from the Hail region with GPS coordinates $(27029 \backslash 05 \backslash \backslash \mathrm{N}$,

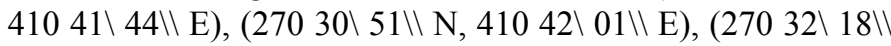
N, $41041 \backslash 42 \backslash \backslash \mathrm{E}),(2600 \backslash 21 \backslash \backslash \mathrm{N}, 40028 \backslash 20 \backslash \backslash \mathrm{E})$, Saudi Arabia. The plant was identified and the specimen deposited in the Herbarium of the Department of Biology, University of Hail. The bark of plant was broken into pieces and air dried.

\section{Preparation of the plant extract}

The dried bark of Ziziphus spina-christi (L.) (5.2 kg) were extracted with absolute ethanol repeatedly (3 times $\times 20 \mathrm{~L}$ ). The ethanol extract was filtered and concentrated under reduced pressure $(119.59 \mathrm{~g})$. The yield $\%$ was $2.3 \%$. The ethanol extract was then fractionated using diethyl ether, chloroform, ethyl acetate and finally with n-butanol. The diethyl ether, chloroform, ethyl acetate and butanol fractions were filtrated and dehydrated over anhydrous sodium sulphate and concentrated under reduced pressure. The yield \% of these fractions was $41.19 \mathrm{~g}, 8.45 \mathrm{~g}, 7.24 \mathrm{~g}$ and $8.86 \mathrm{~g}$, respectively.

\section{GC-MS analysis}

The samples were subjected to GC-MS analysis (Thermo Scientific ISQ LT Trace 1310). Injector temperature was $250^{\circ} \mathrm{C}$, and column description: TG-SQC GC Column $15 \mathrm{~m} \mathrm{x}$ $0.25 \mathrm{~mm} \times 0.25 \mathrm{~mm}$, Temperature programming was maintained from $50^{\circ} \mathrm{C}$ to $290^{\circ} \mathrm{C}$ with constant rise as follows: Oven temperature was initially $50^{\circ} \mathrm{C}$, increased up to $150^{\circ} \mathrm{C}$ at a rate of $7^{\circ} \mathrm{C} / \mathrm{min}$ (held for $1 \mathrm{~min}$ ), increased up to $250^{\circ} \mathrm{C}$ at a rate of $5^{\circ} \mathrm{C} / \mathrm{min}$ (held for $5 \mathrm{~min}$ ) and finally increased up to $290^{\circ} \mathrm{C}$ at a rate of $10^{\circ} \mathrm{C} / \mathrm{min}$ (held for $2 \mathrm{~min}$ ). The ion source and MS transfer line temperatures were $300^{\circ} \mathrm{C}$. The crudes were injected with a splitless mode. Mass spectra were taken at $70 \mathrm{eV}$; fragments from 40 to 1000 Dalton. The final confirmation of constituents was made by computer matching of the mass spectra of peaks with the Wiley and National Institute Standard and Technology (NIST) libraries mass spectral database.

\section{Phytochemical screening}

Ziziphus spina-christi (L.) bark extracts were subjected to qualitative phytochemical analysis for the presence of various classes of active chemical constituents such as tannins, saponins, glycosides, flavonoids, alkaloids, terpenes, steroids, etc. using standard procedures [24,25].

\section{Results and Discussion}

GC-MS analysis was carried out in organic crude extracts (diethylether, chloroform, ethyl acetate and butanol extracts) fractionated from the ethanol extract of the stem bark of Ziziphus spina-christi (L.). The comparison of the mass spectrums with the data base gave more than $90 \%$ match.

\section{Chemical composition of diethyl ether extract of Ziziphus spina-christi (L.)}

Table 1. Identified compounds in diethyl ether extract of Ziziphus spina-christi (L.).

\begin{tabular}{|c|c|c|c|}
\hline RT (min) & Identified compounds & $\begin{array}{l}\text { Chromatogram \% } \\
\text { area }\end{array}$ & MW \\
\hline 7.34 & 3-dodecene, (Z)- & 3.15 & 168 \\
\hline 11.09 & 1-tetradecene & 19.84 & 196 \\
\hline 13.18 & Butyl hydroxytoluene & 7.00 & 220 \\
\hline 14.50 & 1-hexadecanol & 21.30 & 242 \\
\hline 18.26 & 1-hexadecanol, 2-methyl & 17.82 & 256 \\
\hline 22.04 & $\begin{array}{l}\text { Hexadecanoic acid, ethyl ester } \\
\text { (Ethyl palmitate) }\end{array}$ & 18.94 & 284 \\
\hline 25.01 & Ethyl linoleate & 3.65 & 308 \\
\hline 25.11 & $\begin{array}{l}\text { (9-octadecenoic acid (Z)-, ethyl } \\
\text { ester) ethyl oleate }\end{array}$ & 5.68 & 310 \\
\hline 25.61 & $\begin{array}{l}\text { Octadecanoic acid, ethyl ester } \\
\text { (Ethyl stearate) }\end{array}$ & 2.62 & 312 \\
\hline
\end{tabular}

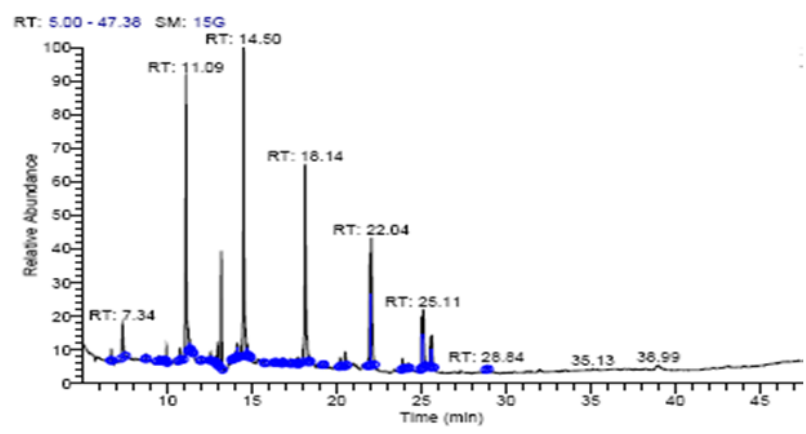

Figure 1. GC-MS chromatogram of diethyl ether extract of Ziziphus spina-christi (L.).

The diethyl ether extract was found to contain nine different compounds, representing $100 \%$ of the total extract. The identified compounds are listed in Table 1 according to their elution order on TG-SQC GC Column (Figure 1). The major compounds detected were 1-Hexadecanol (21.30\%), hexadecanoic acid, ethyl ester (Ethyl palmitate) (18.94\%) and 1-Hexadecanol, 2-methyl (17.82\%). The volatile constituents of the leaves oil of Iranian Ziziphus spina-christi (L.) is also 
reported to have hexadecanol as a main component $(9.7 \%)$ [26]. Octadecanoic acid, ethyl ester (Ethyl stearate) $(2.62 \%)$ were also found to be the minor components of the diethyl ether extract.

\section{Chemical composition of chloroform extract of Ziziphus spina-christi (L.)}

Table 2. Identified compounds in chloroform extract of Ziziphus spinachristi (L.).

\begin{tabular}{|c|c|c|c|}
\hline RT (min) & Identified compounds & $\begin{array}{l}\text { Chromatogram } \\
\% \text { area }\end{array}$ & MW \\
\hline 9.01 & $\begin{array}{l}\text { Pyrrolidine, } 1-(1,6- \\
\text { dioxooctadecyl)-pyrrolidine, }\end{array}$ & 1.22 & 351 \\
\hline 11.22 & $\begin{array}{l}\text { Dichloroacetic acid, tetradecyl } \\
\text { ester }\end{array}$ & 2.33 & 324 \\
\hline 12.84 & $\begin{array}{l}\text { 2,6,10,15-tetramethyl } \\
\text { heptadecane, }\end{array}$ & 1.94 & 296 \\
\hline 12.96 & $\begin{array}{l}\text { Quercetin, quercetin } 7,3^{\prime}, 4^{\prime}- \\
\text { trimethoxy } 4 \mathrm{H}-1 \text {-benzopyran-4- } \\
\text { one, } \\
\text { dimethoxyphenyl)-3,5- } \\
\text { dihydroxy-7-methoxy- }\end{array}$ & 0.46 & 344 \\
\hline 13.17 & Butylated hydroxytoluene & 1.96 & 220 \\
\hline 14.5 & 1-hexadecanol & 2.27 & 242 \\
\hline 14.61 & Octadecane, 1-chloro- & 4.67 & 288 \\
\hline 18.26 & 1-hexadecanol, 2-methyl & 4.95 & 256 \\
\hline 20.59 & $\begin{array}{l}\text { 7,9-di-tert-butyl-1-oxaspiro(4, } \\
\text { 5)deca-6,9-diene-2,8-dione }\end{array}$ & 8.30 & 276 \\
\hline 22.08 & Hexadecanoic acid, ethyl ester & 8.69 & 284 \\
\hline 25.11 & $\begin{array}{l}\text { (9-Octadecenoic acid } \quad(Z)-\text {, } \\
\text { ethyl ester) Ethyl oleate }\end{array}$ & 3.38 & 310 \\
\hline 25.64 & Ethyl stearate & 1.40 & 312 \\
\hline 29.25 & $\begin{array}{l}\text { Phenol, } 2,2 \text { '-methylenebis(6- } \\
\text { (1,1-dimethyl ethyl)-4-methyl- }\end{array}$ & 1.89 & 340 \\
\hline 42.17 & Stigmasterol & 0.65 & 412 \\
\hline 43.21 & a-Sitosterol & 0.68 & 414 \\
\hline 43.64 & Betulin & 55.23 & 442 \\
\hline
\end{tabular}

From Table 2, it's clear that the chloroform extract contain 16 different compounds, representing $100 \%$ of the total extract. The identified compounds are listed in Table 2 according to their elution order on TG-SQC GC Column (Figure 2). The major compounds detected were betulin (55.23\%), hexadecanoic acid ethyl ester (8.69\%), 7, 9-di-tert-butyl-1oxaspiro $(4,5)$ deca-6,9-diene-2,8-dione $(8.30 \%)$. As shown in the table, quercetin $(0.46 \%)$, stigmasterol $(0.65 \%)$ and $\alpha$ Sitosterol $(0.68 \%)$ were present in minor quantities in the chloroform extract. The methanol extract of ripe edible fruits of Ziziphus spina-christi (L.) and Z. jujuba are also reported to contain quercetin [27].

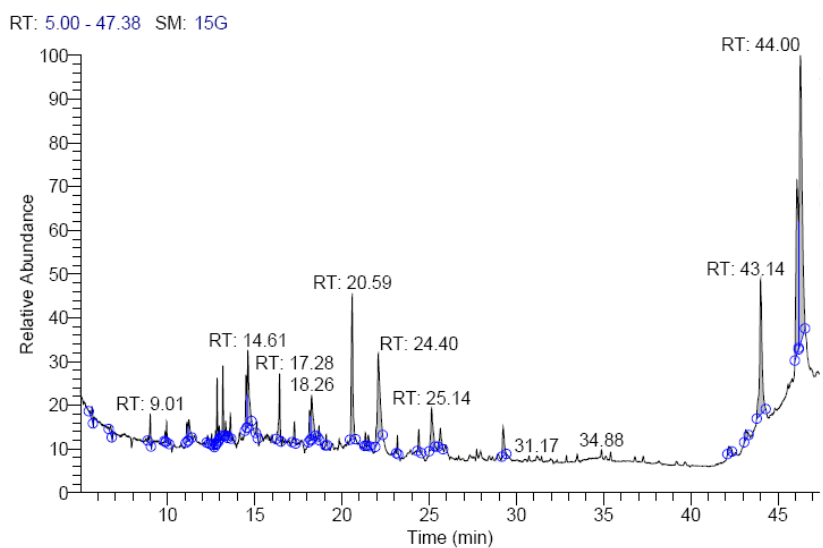

Figure 2. GC-MS chromatogram of chloroform extract of Ziziphus spina-christi (L.).

\section{Chemical composition of ethyl acetate extract of Ziziphus spina-christi (L.)}

Table 3. Identified compounds in ethyl acetate extract of Ziziphus spina-christi (L.).

\begin{tabular}{|c|c|c|c|}
\hline RT (min) & Identified compounds & $\begin{array}{l}\text { Chromatogram } \\
\text { area }\end{array}$ & $\% \quad M W$ \\
\hline 12.81 & $\begin{array}{l}\text { Lanceol, cis (2E)-2-(4,7- } \\
\text { Dimethyl-3,4,4a,5,6,8a- } \\
\text { hexahydro-1(2H)- } \\
\text { naphthalenylidene)-1-propanol }\end{array}$ & 3.87 & 220 \\
\hline 20.78 & $\begin{array}{l}\text { Hexadecanoic acid, methyl } \\
\text { ester (Palmetic methyl ester) }\end{array}$ & 2.15 & 270 \\
\hline 23.82 & $\begin{array}{l}\text { 8,11-Octadecadienoic acid, } \\
\text { methyl ester }\end{array}$ & 1.80 & 294 \\
\hline 23.92 & $\begin{array}{l}\text { 9-Octadecenoic acid (Z)-, } \\
\text { methyl ester (Methyl oleate) }\end{array}$ & 4.65 & 296 \\
\hline 24.19 & $\begin{array}{l}\text { Phytol (2-Hexadecen-1-ol, } \\
3,7,11,15 \text {-tetramethyl-, } \quad\left(\mathrm{R}-\left(\mathrm{R}^{*},\right.\right. \\
\left.\left.\left.\mathrm{R}^{*}-(\mathrm{E})\right)\right)-\right)\end{array}$ & 2.66 & 296 \\
\hline 36.13 & Heptacosane & 2.44 & 380 \\
\hline 41.49 & Campesterol & 2.92 & 400 \\
\hline 42.18 & Stigmasterol & 15.98 & 412 \\
\hline 43.21 & a-Sitosterol & 43.89 & 414 \\
\hline 43.64 & Betulin & 15.45 & 442 \\
\hline 44.8 & Ethyl iso-allocholate & 4.20 & 436 \\
\hline
\end{tabular}

The ethyl acetate extract was found to contain 11 different compounds, representing $100 \%$ of the total extract. The identified compounds are listed in Table 3 according to their elution order on GC column (Figure 3 ). The major compounds detected were $\alpha$-sitosterol (43.89\%), stigmasterol (15.98\%), and betulin $(15.45 \%)$. The minor components of the ethyl acetate extract are found to be 8,11-octadecadienoic acid, methyl ester $(1.80 \%)$, hexadecanoic acid, methyl ester (Palmetic methyl ester) $(2.15 \%)$ and phytol (2-hexadecen-1-ol, 3,7,11,15-tetramethyl-, (R-(R*, R*-(E)))) (2.66\%). The oil from 
the aerial parts of $Z$. jujuba is also reported to contain phytol [28].

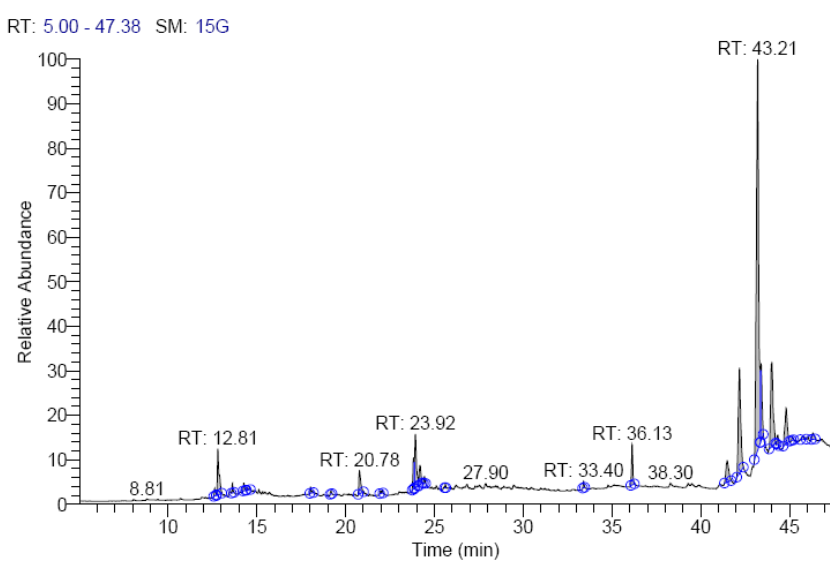

Figure 3. GC-MS chromatogram of ethyl acetate extract of Ziziphus spina-christi (L.).

\section{Chemical composition of butanol extract of $Z$. spina- christi}

Table 4. Identified compounds in butanol extract of Z. spina-christi.

\begin{tabular}{llll}
\hline RT (min) & Identified compounds & $\begin{array}{l}\text { Chromatogram } \\
\text { area }\end{array}$ & MW \\
\hline 6.46 & 1,2-dihydeo-4-ethoxy-2-quinol one & 4.71 & 189 \\
\hline 8.72 & 1-butoxy-1-isobutoxy-butane & 5.3 & 202 \\
\hline 18.90 & 9-octadecenoic acid (Z)- oleic acid & 1.82 & 282 \\
\hline 19.62 & $\begin{array}{l}\text { Cholestan-3-ol, 2-methylene-, (3á, } \\
\text { 5à)- }\end{array}$ & 1.83 & 400 \\
\hline 21.79 & 1,1-Dimethyltetradecylhydrosulfide & 5.52 & 258 \\
\hline 23.62 & Dotriacontane & 6.58 & 450 \\
\hline 23.90 & Phytol & 21.31 & 296 \\
\hline 24.38 & 14-a-H-pregna & 11.59 & 288 \\
\hline 29.84 & Di-(9-octadecenoyl)-glycerol & 6.78 & 620 \\
\hline 32.48 & Z,Z-4,16-octadecadien-1-ol acetate & 3.44 & 308 \\
\hline
\end{tabular}

\begin{tabular}{llll}
\hline 42.17 & Stigmasterol & 4.26 & 412 \\
\hline 43.21 & $\begin{array}{l}\text { á-Sitosterol } \\
(3 a ́)-)\end{array}$ & (Stigmast-5-en-3-ol, & 23.51 \\
\hline 43.64 & Betulin & 3.45 & 414 \\
\hline
\end{tabular}

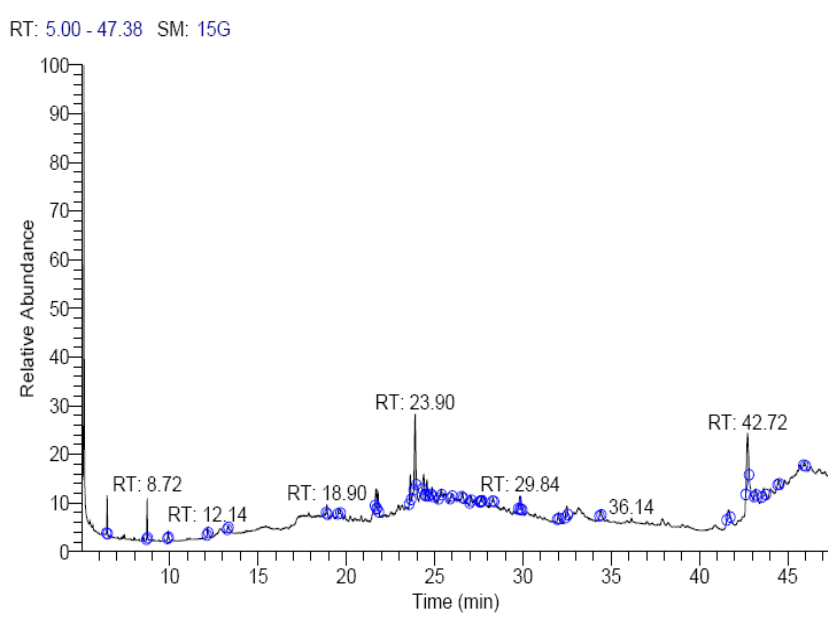

Figure 4. GC-MS chromatogram of butanol extract of Ziziphus spinachristi (L.).

The n-butanol extract was found to contain 13 different compounds, representing $100.1 \%$ of the total extract. The identified compounds are listed in Table 4 according to their elution order on TG-SQC GC column (Figure 4). The major compounds detected were á-sitosterol stigmast-5-en-3-ol, (3á)(23.51\%), phytol (21.31\%) and 14-á-H-pregna (11.59\%). Interestingly, phytol is also present as the main constituents of the oil from the aerial parts of Z. jujuba (29.1\%) [27]. As shown in Table 4, 9-octadecenoic acid (Z)-oleic acid (1.82\%), cholestan-3-ol, 2-methylene-, (3á, 5à) (1.83\%), Z,Z-4,16Octadecadien-1-ol acetate $(3.44 \%)$ and betulin $(3.45 \%)$ were also found to be the minor components of the n-butanol extract.

\section{Comparison between different extracts of Ziziphus spina-christi (L.)}

Table 5. Comparison between different extracts of Ziziphus spina-christi (L.).

\begin{tabular}{|c|c|c|c|c|c|}
\hline RT (min) & Identified compounds & Diethyl ether extract & $\begin{array}{l}\text { Chloroform } \\
\text { extract }\end{array}$ & Ethyl acetate extract & $\begin{array}{l}\text { n-butanol } \\
\text { Extract }\end{array}$ \\
\hline 6.46 & 1,2-Dihydeo-4-ethoxy-2-quinolone & - & - & - & + \\
\hline 7.34 & 3-Dodecene, (Z)- & + & - & - & - \\
\hline 8.72 & 1-butoxy-1-isobutoxy-butane & - & - & - & + \\
\hline 9.01 & Pyrrolidine,1-(1,6-dioxooctadecyl)-pyrrolidine, & - & + & - & - \\
\hline 11.09 & 1-Tetradecene & + & - & - & - \\
\hline 11.22 & Dichloroacetic acid, tetradecyl ester & - & + & - & - \\
\hline 12.81 & $\begin{array}{l}\text { Lanceol, } \quad \text { cis(2E)-2-(4,7-dimethyl-3,4,4a,5,6,8a- } \\
\text { hexahydro-1(2H)-naphthalenylidene)-1-propanol }\end{array}$ & - & - & + & - \\
\hline
\end{tabular}




\begin{tabular}{|c|c|c|c|c|c|}
\hline 12.84 & 2,6,10,15-tetramethyl heptadecane, & - & + & - & - \\
\hline 12.96 & 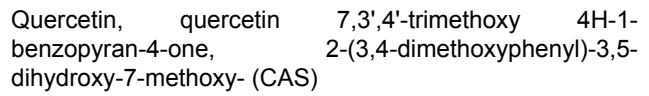 & - & + & - & - \\
\hline 13.17 & Butyl hydroxytoluene & + & + & - & - \\
\hline 14.5 & 1-Hexadecanol & + & + & - & - \\
\hline 14.61 & Octadecane, 1-chloro- & - & + & - & - \\
\hline 18.26 & 1-hexadecanol, 2-methyl & + & + & - & - \\
\hline 18.9 & 9-Octadecenoic acid (Z)-Oleic acid & - & - & - & + \\
\hline 19.62 & Cholestan-3-ol, 2-methylene-, (3á,5à)- & - & - & - & + \\
\hline 20.59 & 7,9-Di-tert-butyl-1-oxaspiro(4,5)deca-6,9-diene-2,8-dione & - & + & - & - \\
\hline 20.78 & Hexadecanoic acid, methyl ester (Palmetic methyl ester) & - & - & + & - \\
\hline 21.79 & 1,1-Dimethyltetradecylhydrosulfide & - & - & - & + \\
\hline 22.04 & Hexadecanoic acid, ethyl ester(Palmitic acid, ethyl ester) & + & - & - & - \\
\hline 23.62 & Dotriacontane & - & - & - & + \\
\hline 23.82 & 8,11-Octadecadienoic acid, methyl ester & - & - & + & - \\
\hline 23.92 & 9-Octadecenoic acid (Z)-, methyl ester (Methyl oleate) & - & - & + & - \\
\hline 24.19 & $\begin{array}{l}\text { Phytol (2-Hexadecen-1-ol, 3,7,11,15-tetramethyl-, } \quad \text { (R- } \\
\left.\left.\left(R^{*}, R^{*}-(E)\right)\right)-\right)\end{array}$ & - & - & + & + \\
\hline 24.38 & 14-á-H-Pregna & - & - & - & + \\
\hline 25.01 & Ethyl linoleate & + & - & - & - \\
\hline 25.11 & (9-Octadecenoic acid (Z)-, ethyl ester) ethyl oleate & + & + & - & - \\
\hline 25.61 & Octadecanoic acid, ethyl ester (Ethyl stearate) & + & + & - & - \\
\hline 29.25 & Phenol,2,2'-methylenebis(6-(1,1-dimethylethyl)-4-methyl- & - & + & - & - \\
\hline 29.84 & DI-(9-Octadecenoyl)-glycerol & - & - & - & + \\
\hline 32.48 & Z,Z-4,16-Octadecadien-1-ol acetate & - & - & - & + \\
\hline 36.13 & Heptacosane & - & - & + & - \\
\hline 41.49 & Campesterol & - & - & + & - \\
\hline 42.17 & Stigmasterol & - & + & + & + \\
\hline 43.21 & á-Sitosterol Stigmast-5-en-3-ol, (3á)- & - & + & + & + \\
\hline 43.64 & Betulin & - & + & + & + \\
\hline 44.8 & Ethyl iso-allocholate & - & - & + & - \\
\hline
\end{tabular}

Comparing the chemical components of different extracts of Ziziphus spina-christi (L.) showed that few compounds are specifically present in certain extracts. tradecene, hexadecanoic acid, ethyl ester (ethyl palmitate), and ethyl linoleate are found only in diethyl ether extract. Seven different compounds are only found in the chloroform extract, namely pyrrolidine, 1(1,6-dioxooctadecyl)-pyrrolidine; 2,6,10,15-tetramethyl heptadecane; quercetin, quercetin 7,3',4'-trimethoxy 4H-1benzopyran-4-one, 2-(3,4-dimethoxyphenyl)-3,5-dihydroxy-7methoxy; octadecane, 1-chloro-; 7,9-di-tert-butyl-1- oxaspiro(4,5)deca-6,9-diene-2,8-dione; phenol, 2,2'methylenebi([6-(1,1-dimethylethyl)-4-methyl-. The ethyl acetate extract alone, when compared with other extracts, had contained the following seven compounds: Lanceol, cis (2E)-2(4,7-dimethyl-3,4,4a,5,6,8a-hexahydro-1(2H)-

naphthalenylidene)-1-propanol; hexadecanoic acid, methyl ester (Palmetic methyl ester); 8,11-octadecadienoic acid, methyl ester; 9-octadecenoic acid (Z)-, methyl ester (Methyl oleate); heptacosane; campesterol; and ethyl iso-allocholate. The butanol extract alone, when compared with other extracts, 
had contained the following nine compounds: 1,2-dihydeo-4ethoxy-2-quinol one; 1-butoxy-1-isobutoxy-butane; 9octadecenoic acid (Z)-oleic acid; Cholestan-3-ol, 2-methylene-, (3á,5à)-; 1,1-dimethyltetradecylhydrosulfide; dotriacontane; 14-á-H-PREGNA; Di-(9-octadecenoyl)-glycerol; and Z,Z-4,16-octadecadien-1-ol acetate.

There are some compounds present in many extracts (Table 5 and Figure 5). Butyl hydroxytoluene (1) (BHT) also known as dibutylhydroxy toluene, is a lipophilic organic compound, chemically a derivative of phenol, that is useful for its antioxidant properties [29]. BHT is also used to prevent peroxide formation in diethyl ether and other laboratory chemicals. For example, Sigma Aldrich mentioned that 'Diethyl ether contains 1 ppm BHT as inhibitor, anhydrous, $\geq$ 99.7\%' (Retrieved 11 September 2012). To make sure if the natural origin of BHT and not diethyl ether we inject diethyl ether as blank that gave negligible peak area compared to the main peak., 1-hexadecanol (2), 1-hexadecanol, 2-methyl (3), (9-octadecenoic acid (Z)-, ethyl ester) ethyl oleate (4) and octadecanoic acidethyl ester (Ethyl stearate) (5) were exist in both diethyl ether extract $(7.00 \%, 21.30 \%, 17.82 \%, 5.68 \%$ and $2.62 \%$, respectively) and chloroform extract $(1.96 \%, 1.99 \%$, $3.03 \%, 3.38 \%, 1.23 \%$, respectively).

Phytol (6) was present in n-butanol extract (21.31\%) in higher concentration as compared with ethyl acetate extract $(2.66 \%)$. Stigmasterol (7), sitosterol (Stigmast-5-en-3-ol, (8) and betulin (9) were found in three extracts (chloroform, ethyl acetate and butanol extracts). Stigmasterol (7) was present in ethyl acetate extract $(15.98 \%)$ in large quantities as compared to butanol extract $(4.26 \%)$ and chloroform extract $(0.65 \%)$. á-Sitosterol (Stigmast-5-en-3-ol) (8) was present in ethyl acetate extract in large quantity $(43.89 \%)$, more than that present in butanol extract $(23.51 \%)$ and chloroform extract (0.68\%). Betulin (9) was present in chloroform extract in large quantity $(55.23 \%)$ as compared to ethyl acetate $(15.45 \%)$ and butanol $(3.45 \%)$ extracts.

Table 6. Phytochemical constituants of extracts of Z. spina-christi stem-bark.

\begin{tabular}{|c|c|c|c|c|c|}
\hline $\begin{array}{l}\text { Chemical } \\
\text { constituents }\end{array}$ & $\begin{array}{l}\text { Ethanol } \\
\text { extract }\end{array}$ & $\begin{array}{l}\text { Diethyl } \\
\text { ether } \\
\text { extract }\end{array}$ & $\begin{array}{l}\text { Chlorofor } \\
\text { m extract }\end{array}$ & $\begin{array}{l}\text { Ethyl } \\
\text { acetate } \\
\text { extract }\end{array}$ & $\begin{array}{l}\text { n-butanol } \\
\text { extract }\end{array}$ \\
\hline $\begin{array}{l}\text { Saponin } \\
\text { glycosides }\end{array}$ & + & + & + & ++ & +++ \\
\hline Carbohydrate & + & - & - & + & ++ \\
\hline Flavonoids & + & + & + & + & ++ \\
\hline Terpernoids & + & + & + & ++ & ++ \\
\hline Alkaloids & + & + & + & + & ++ \\
\hline $\begin{array}{l}\text { Anthraquinon } \\
\mathrm{e}\end{array}$ & - & - & - & - & - \\
\hline
\end{tabular}

+++: Strong intensity reaction; ++: Medium intensity reaction; +: Weak intensity reaction; -: Nondetected.

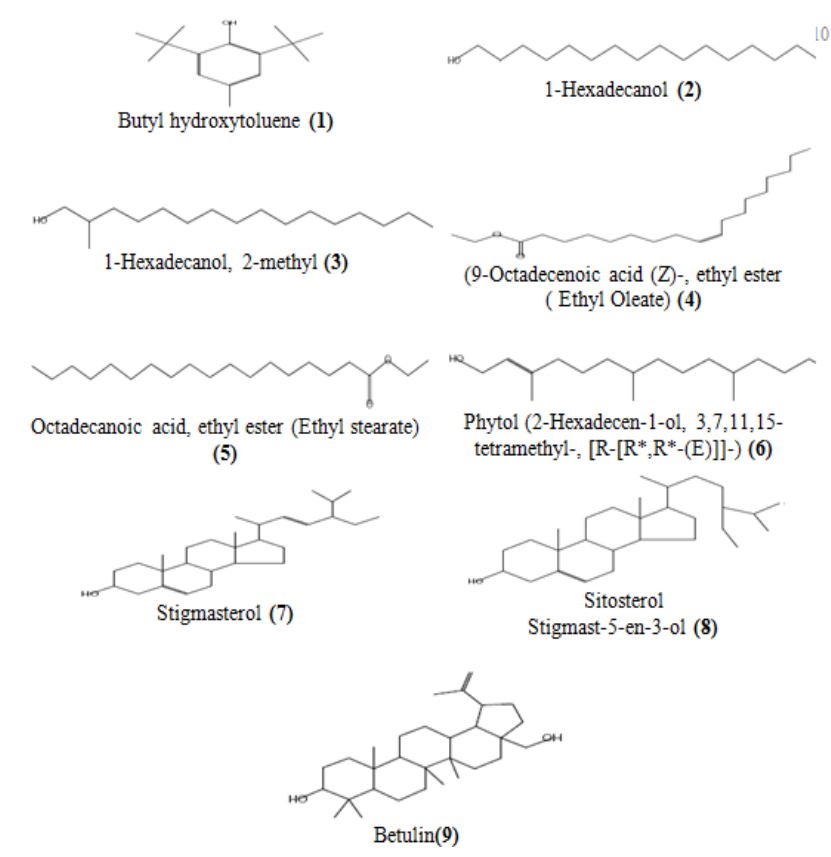

Figure 5. Chemical structures of different chemical compounds identified in the stem bark of Z. spina-christi (Wiley and National Institute Standard and Technology (NIST) libraries mass spectral database of $G C-M S)$.

From the above Table 6, it's clear that the phytochemical screening for ethanolic extract, diethyl ether extract, chloroform extract and n-butanol extract showed presence of flavonoids, terpenoids and saponin glycosides and alkaloids. The butanol extract is the best one. While free and combined anthraquinones were absent, carbohydrates were also absent in both diethyl ether and chloroform extracts.

Phytochemical analysis of Ziziphus spina-christi (L.) leaves showed the presence of four saponin glycosides in the butanol extract [22]. As christinin-A was the major saponin glycoside, the butanol extract and chistinin-A were used to evaluate the potential antidiabetic activity and toxicity of Ziziphus spinachristi (L.) leaves [30]. Preliminary phytochemical analysis showed the presence of major classes of secondary metabolites such as tannins, alkaloids, flavonoids, cardiac glycosides, etc. in both of the extracts. Saponins, protein and amino acids were absent in both the extracts. Seed extract showed the absence of steroids and terpenoids while their presence was revealed in fruit extract [31].

\section{Conclusion}

In GC-MS analysis, 36 different chemical compounds were identified in the stem bark of Z. spina-christi. Diethylether, chloroform, ethyl acetate and butanol extracts fractionated from the ethanol extract of Ziziphus spina-christi (L.) contain 9, 17, 11 and 13 compounds, respectively. Diethyl ether extract is better than chloroform extract for isolation of butyl hydroxytoluene, 1-hexadecanol, 1-hexadecanol, 2-methyl, (9octadecenoic acid (Z)-, ethyl ester) ethyl oleate and 
octadecanoic acid, ethyl ester (Ethyl stearate). Phytol was isolated effectively by n-butanol than ethyl acetate from the ethanolic extract of $Z$. spina-christi. Stigmasterol, á-Sitosterol Stigmast-5-en-3-ol, (3á) was isolated from ethanolic extract of Ziziphus spina-christi (L.) using ethyl acetate. Betulin was present in chloroform extract in large quantity as compared with ethyl acetate and butanol extracts. Butanol extract of Ziziphus spina-christi (L.) is rich in carbohydrates, flavonoids, terpenoids and saponin glycosides and alkaloids compared to other extracts. Further detailed investigations on the isolated compounds are needed to identify the phytoconstituents and study there antimicrobial and cytotoxic activities.

\section{Acknowledgments}

This work was supported by King Abdulaziz City for Science and Technology (Grant No. p 88-35).

\section{Conflicts of Interest}

None

\section{References}

1. Mandaville JP. Flora of Eastern Saudi Arabia. Kindling and status epilepticus models of epilepsy: rewiring the brain. Prog Neurobiol 1990; 73: 1-7.

2. Ghazanfar SA. Handbook of Arabian medicinal plants. CRC Press Boca Raton 1994.

3. Ghafoor AO, Qadir HK, Fakhri NA. Analysis of phenolic compounds in extracts of Ziziphus spina-christi using RPHPLC methods. J Chem Pharm Res 2012; 4: 3158-3163.

4. Shahat AA, Pieter L, Apers S, Nazif NM, Abdel-Azim NS, Berghe DV, Taeckholm V. Students Flora of Egypt. Cairo University, Cairo, Egypt 1974.

5. Dalziel JM. The useful plants of West tropical Africa. Crown Agent for Colonies London 1937.

6. Hutchens AR. Indian hierology of North America. Ontario, Canada: Mero 1973.

7. Shahat AA, Pieters L, Apers S, Nazif NM, Abdel Azim NS, Berghe DV, Vlietinck AJ. Chemical and biological investigations of Zizyphus spina-christi L. Phytother Res 2001; 15: 593-507.

8. Nazif NM. Phytoconstituents of Zizyphus spina-Christi L. fruits and their antimicrobial activity. Food Chem 2002; 76: 77-81.

9. Adzu B, Amos S, Wambebe C, Gamaniel K. Antinociceptive activity of Zizyphus spina-christi root bark extract. Fitoterapia 2001; 72: 344-350.

10. Adzu B, Amos S, Dzarma S, Wambebe C, Gamaniel K. Effect of Zizyphus spina-christi Willd aqueous extract on the central nervous system in mice. J Ethnopharmacol 2002; 79: 13-16.

11. Adzu B, Amos S, Amizan MB, Gamaniel K. Evaluation of the antidiarrheal effects of Zizyphus spina-christi stem bark in rats. Acta Tropica 2003; 7: 245-250.
12. Barboni L, Gariboldi P, Torregiani E, Verotta L. Cyclopeptie alkaloid from Zizyphus mucronata. Phytochemistry 1994; 35: 1579-1583.

13. Abu-Zarga M, Sabri S, Al-Aboudi A. New cyclopeptide alkaloids from Zizyphus lotus, J Nat Prod 1995; 58: 504-511.

14. Cheng G, Bai Y, Zhao Y, Tao J, Liu Y, Tu G, Ma L, Liao N, $\mathrm{Xu}$ X. Flavonoids from Zizyphus jujube Mill var. Spinosa. Tetrahedron 2000; 56: 8915-8920.

15. Tripathi M, Pandey MB, Jha RN, Pandey VB, Tripathi PN, Singh JP. Cyclopeptide alkaloids from Zizyphus jujuba. Fitoterapia 2001; 72: 507-510.

16. Ads E, Rajendrasozhan S, Hassan S, Sharawy S, Humaidi J. Phytochemical, antimicrobial and cytotoxic evaluation of Ziziphus spina-christi (L.) stem bark. Biomed Res 2017; 28: 6646-6653.

17. Mahran GH, Glombitza KW, Mirhom YW, Hartmann R, Michel CG. Novel saponins from Zizyphus spina-christi growing in Egypt. Planta Medica 1996; 62: 163-165.

18. Sirikhansaeng P, Tanee T, Sudmoon R, Chaveerach A. Major phytochemical as $\gamma$-sitosterol disclosing and toxicity testing in Lagerstroemia species. Evid Based Compl Alt Med 2017; 2017.

19. Cheng G, Bai Y, Zhao Y, Tao J, Liu Y, Tu G, Ma L, Liao N, $\mathrm{Xu}$ X. Flavonoids from Zizyphus jujuba Mill var. spinosa. Tetrahedron 2000; 56: 8915-8920.

20. Shahat AA, Pieters L, Apers S, Nazeif NM, Abdel-Azim NS, Berghe DV, Vlietinck AJ. Chemical and biological investigations on Zizyphus spina-christi L. Phytother Res 2001; 15: 593-597.

21. Tripathi M, Pandey MB, Jha RN, Pandey VB, Tripathi PN, Singh JP. Cyclopeptide alkaloids from Zizyphus jujuba. Fitoterapia 2001; 72: 507-510.

22. Mahran GH, Glombitza KW, Mirhom YW, Hartmann R, Michel CG. Novel saponins of Zizyphus spina-christi (L.) Willd cultivated in Egypt. Planta Medica 1996; 62: 163-165.

23. Adzu B, Amos B, Wambebe SC, Gamaniel K. Antinoeiceptive activity of Zizyphus spina-christi root bark extract. Fitoterapia 2001; 72: 344-350.

24. Mohammed GT, Yesufu HB, Abdulrahman FI, Muazul J, Yakubu SI, Sadiq GU, Wazis CH. Antimicrobial and toxicological screening of the aqueous stem bark extract of Zizyphus spina-christi (Linnaeus Desf). J Microbiol Biotechnol Res 2012; 2: 337-342.

25. Chothani DL, Patel NM. Preliminary phytochemical screening, pharmacognostic and physicochemical evalution of leaf of Gmelina arborea. Asian Pac J Trop Biomed 2012; 2: 1333-1337.

26. Ghannadi A, Tavakoli N, Mehri M. Volatile constituents of the leaves of Ziziphus spina-christi (L.) Willd. from Bushehr, Iran. J Essent Oil Res 2003; 15: 191-192.

27. Pawlowska AM, Camangi F, Bader A, Braca A. Flavonoids of Zizyphus jujuba L. and Zizyphus spina-christi (L.) Willd (Rhamnaceae) fruits. Food Chem 2009; 112: 858-862. 
28. Said A, Fawzy G, Ali Abu Tabl E, Tzakou O. Volatile constituents of Zizyphus jujuba aerial parts and Zizyphus spina-christii fruits from Egypt. J Essent Oil Bear Plants 2010; 13: 170-174.

29. Yehye WA, Rahman NA, Ariffin A, Abd H, Sharifah B; Alhadi AA, Kadir FA, Yaeghoobi M. Understanding the chemistry behind the antioxidant activities of butylated hydroxytoluene (BHT): A review. Eur J Med Chem 2015; 101: 295-312.

30. Mosmann T. Rapid colorimetric assay for cellular growth and survival: application to proliferation and cytotoxicity assays. J Immunol Met 1983; 65: 55-63.

31. Alhakmani F, Khan SA, Ahmad A. Determination of total phenol, in-vitro antioxidant and anti-inflammatory activity of seeds and fruits of Zizyphus spina-christi grown in Oman. Asian Pac J Trop Biomed 2014; 4: 656-660.

\section{*Correspondence to}

Essam Nabih Ads

Department of Chemistry

Faculty of Science

University of Hail

Saudi Arabia 